\title{
Chemical Characterization of Water-soluble Ions and Metals in Particulate Matter Generated by a Portable Two-stroke Gasoline Engine
}

\author{
Jen-Hsiung Tsai ${ }^{1}$, Shui-Jen Chen ${ }^{1 *}$, Sheng-Lun Lin ${ }^{2,3}$, Zheng-You $\mathrm{Xu}^{1}$, \\ Kuo-Lin Huang ${ }^{1}$, Chih-Chung Lin ${ }^{1}$ \\ ${ }^{1}$ Department of Environmental Science and Engineering, National Pingtung University of \\ Science and Technology, Pingtung 91201, Taiwan \\ ${ }^{2}$ School of Mechanical Engineering, Beijing Institute of Technology, Beijing 100081, China \\ ${ }^{3}$ Center for Environmental Toxin and Emerging-contaminant Research, Cheng Shiu University, \\ Kaohsiung 83347, Taiwan
}

\section{ABSTRACT}

To examine the characteristics of water-soluble ions and metals on the particulate matter (PM) in the exhausts, a P2SGE (portable two-stroke gasoline engine) was fueled by unleaded gasoline \#92 blended with different two-stroke engine oil brands (CPC Super Low Smoke Two-Stork Engine Oil (SLS), CPC Low Smoke Two-Stroke Engine Oil (LS), and MERCURY STAR (MS)) and operated under idling, mid-load (1.5 kW), and high-load (1.9 kW), respectively. Experimental results reveal that the PM mass concentrations in the exhausts were in the order MS (avg. 1,934 $\mathrm{mg} \mathrm{Nm}^{-3}$ ) > SLS (avg. 1,543 $\mathrm{mg} \mathrm{Nm}^{-3}$ ) > LS (avg. 1,167 $\mathrm{mg} \mathrm{Nm}^{-3}$ ) in all test conditions. The mass concentrations and emission factors (EFs) of PM decreased as the P2SGE load increased by adding each tested lubricant. Based on fuel consumption, EFs of $\Sigma$ lons were the lowest when utilizing the LS additive (avg. $89.7 \mathrm{mg} \mathrm{L}$-fuel $^{-1}$ ), followed by the MS and SLS (165 and $168 \mathrm{mg} \mathrm{L-fuel}^{-1}$, in average, respectively); whereas the lowest levels of $\Sigma$ Metals were observed by using MS additive (avg. $61.3 \mathrm{mg} \mathrm{L}^{-1}$ ), followed by using the LS (avg. $83.8 \mathrm{mg} \mathrm{L}^{-1}$ ) and SLS (avg. $85.2 \mathrm{mg} \mathrm{L}^{-1}$ ). The soluble ions on the PM were mostly $\mathrm{Na}^{+}, \mathrm{Ca}^{2+}, \mathrm{NO}_{3}{ }^{-}$, and $\mathrm{SO}_{4}{ }^{2-}$ among eight tested species, which accounted for only 0.05-0.19\% (avg. 0.1\%) of PM mass. The 21 analyzed metal components represented only $0.05 \%$ of the mass of the PM, and were dominated by $\mathrm{Na}, \mathrm{Mg}, \mathrm{Al}, \mathrm{K}, \mathrm{Ca}, \mathrm{Fe}$, and $\mathrm{Zn}$, which represented $98.7 \%$ by mass of $\Sigma$ Metals. Our finding for portable engine emission has been rarely considered in the literature but it is unneglectable for labors who are usually exposed to the ions and metals. Further health risk assessment research is suggested to include temporarily real-life exposures with high pollutant levels.

Received: November 16, 2020

Revised: February 4, 2021

Accepted: February 5, 2021

${ }^{*}$ Corresponding Author:

chensj@mail.npust.edu.tw

\section{Publisher:}

Taiwan Association for Aerosol Research

ISSN: $1680-8584$ print

ISSN: 2071-1409 online

(c) Copyright: The Author(s). This is an open access article distributed under the terms of the Creative Commons Attribution License (CC BY 4.0), which permits unrestricted use, distribution, and reproduction in any medium, provided the original author and source are cited.
Keywords: Portable two-stroke gasoline engine, Particulate matter, Water-soluble ions, Metals, Environmental pollution

\section{INTRODUCTION}

The internal combustion engine (ICE) is one of the greatest inventions in history. It has a high thermal efficiency and high power output and enables vehicles to travel at high speed (with good maneuverability). Since the mid-19th century, ICEs have been used around the world. Almost all motor vehicles, agricultural machinery, engineering machinery, and even power generation equipment, use internal combustion engines to generate power. The working principle of the ICE is that burning fossil fuels (including gasoline, diesel, kerosene, and natural gas) inside the machine releases chemical energy, which is converted to mechanical kinetic energy. This process can provide huge amounts of energy for various activities, but it generates many harmful air pollutants (such as fine particulate matter $\left(\mathrm{PM}_{2.5}\right)$, traditional pollutants, organic/inorganic component species, 
and even toxic compounds) (Lin et al., 2008; Tsai et al., 2018; Lin et al., 2020). Furthermore, when the high-temperature exhaust from an ICE have been discharged into the lower-temperature atmosphere, the low-volatility substances (such as $\mathrm{H}_{2} \mathrm{SO}_{4}$ ) therein may undergo gas-to-particle conversion (nucleation and coagulation reactions); thus, many ultrafine particles with aerodynamic diameters of 10-50 nm are generated (Schneider et al., 2005; Beddows and Harrison, 2008), harming human health, affecting the environment, and contributing to climate change (Ramanathan and Carmichael, 2008; Hao et al., 2010; Ramana et al., 2010).

Generally, the particulate pollutants emitted by gasoline engines consist of mainly: (1) carbon particles after combustion, (2) solvable organic fraction (SOF), mainly from incompletely burned engine oil or fuel, and (3) combustion oxides, including sulfates, nitrates, and phosphates. A study by Sodeman et al. (2005) also revealed that the water-soluble ions on the PM in the exhaust might be contributed by lubricating oil. Vehicle exhaust particles have been proven to harm human health and affect the environment, such as entering a human body through breathing, polluting various environmental media with toxic substances, affecting visibility, and even accelerating global climate change (Maricq, 2007). Once those gasoline-engine exhausts containing watersoluble ions enter the human lungs through respiration, they will readily dissolve in the body fluids on the surface of the trachea due to their hydrophilicity, and thereby cause inflammation or toxicological reactions. Our earlier work showed that the particle-induced cytotoxicity [as CEC (cumene-hydroperoxide equivalent concentration)] correlated more significantly with $\mathrm{NO}_{3}{ }^{-}$, $\mathrm{SO}_{4}{ }^{2-}, \mathrm{NH}_{4}{ }^{+}$, and $\mathrm{Cl}^{-}$, while the contents of sulfate ion $\left(\mathrm{SO}_{4}{ }^{2-}\right)$ and nitrate ion $\left(\mathrm{NO}_{3}{ }^{-}\right)$were positively correlated with the cytotoxicity of $\mathrm{PM}_{10}$ in the atmosphere (Chen et al., 2006). Therefore, the water-soluble ions on the PM that is emitted from two-stroke gasoline engines must be studied to reduce the hazard to operators of exposure to such emissions.

The metal content of the PM in exhausts has always been a critical issue in relation to air pollution (Lin et al., 2005, 2020). Several works have suggested that the main metallic elements in lubricating oil are $\mathrm{Ca}, \mathrm{Zn}$, and $\mathrm{Mg}$, while the primary non-metallic elements are $\mathrm{P}$ and $\mathrm{B}$ (Hu et al., 2009; Liati et al., 2015). Most of the $\mathrm{Fe}, \mathrm{Ni}, \mathrm{Cu}, \mathrm{Cr}$, and $\mathrm{Sb}$ on PM in exhausts come from the wear and tear of engine parts (Lim et al., 2007; Sappok et al., 2012). These trace metals are mainly associated with the compositions of lubricating oils, fossil fuels, additives, and detergents. Consequently, a higher metal content of the fuel corresponds to a higher metal content in the exhaust (Wang et al., 2016). Although the non-road two-stroke gasoline engine emits fewer trace metals, metallic elements are usually tricky to decompose and accumulate in the human body and result in various toxic effects harmful to human health. A study by Chen and Lippmann (2009) found that $\mathrm{Ni}, \mathrm{V}, \mathrm{Pb}$, and $\mathrm{Zn}$ were positively associated with acute cardiac function changes and high short-term mortality. Järup and Åkesson (2009) pointed out that Cd might raise the incidence of kidney disease and was detrimental to bone growth, whereas prolonged exposure to high levels of $\mathrm{Cd}$ even directly damaged bones. Furthermore, epidemiological and toxicological research reports have confirmed that metallic elements on PM may contribute to carcinogenesis (Lippmann et al., 2006; Kawata et al., 2007; Calvo et al., 2013).

Studies have noted that ultrafine particles that are derived from traffic sources can cause serious oxidative pressure in human cell tissues and cause DNA damage (Bräuner et al., 2007; Møller et al., 2008). The International Agency for Research on Cancer (IARC) of the World Health Organization (WHO) announced as long ago as 1989 that "gasoline engine exhaust" is a level 2 human carcinogenic factor (possibly carcinogenic to humans, Group 2B). Although many countries have set relevant emission standards for the exhausts of on-road gasoline-powered equipment (o-RGE, such as motorcycles, four-wheeled vehicles, and buses, and trucks), the emission of air pollutants from non-road gasoline-powered equipment ( $n-R G E$, such as brush cutters, sprayers, and leaf blowers) has attracted relatively little concern. People have long been accustomed to the use of all kinds of equipment that is powered by gasoline engines to perform various economic or non-economic activities to improve work efficiency and to reduce human labor. In particular, emissions from n-RGE that is used in agricultural activities may pollute crops and fruits, increasing the risk associated with their ingestion. Therefore, attention should be paid to the potential risks to human health and the environment of emissions from n-RGE. In order to examine the emission characteristics of P2SGE, a small commonly used sprayer (KAWAGOE, C12E) was used herein as a testing engine. To prepare fuels for testing, unleaded gasoline \#92 was used as the base oil and blended (4 vol.\% two-cycle engine oil + 96 vol.\% gasoline) with one of three two-cycle engine oil 
brands: CPC Super Low Smoke Two-Stroke Engine Oil (CPC-SLS), CPC Low Smoke Two-Stroke Engine Oil (CPC-LS), and MERCURY STAR Two-Stroke Engine Oil (MS). The three lubricants used in this study were the lubricating oils that are commonly available in Taiwan and are relatively inexpensive. The characteristics of water-soluble ions and metal components on PM were measured at various engine loads.

\section{MATERIALS AND METHODS}

\subsection{Instruments and Sampling Methods}

The tested small portable gasoline-powered sprayer (KAWAGOE, Model: C12E) was equipped with a single-cylinder, naturally aspirated, and air-cooled two-stroke gasoline engine (Model: G45H; manufactured by Chaang Cherng Co., Ltd., TAIWAN). The fuel oil mixing ratio (gasoline: two-stroke engine oil), set by its manufacturer, was 25: 1; the cylinder displacement was 41.5 c.c.; and the maximum horsepower was 2.2 ps.

The base oil, unleaded gasoline \#92, was purchased from the CPC (Chinese Petroleum Corporation) in Taiwan. Table 1 presents the physicochemical properties of two-stroke engine oils (SLS, LS, and MS) used in this study.

The flue sampling equipment that was used in this study was consistent with US EPA Method 5. Before sampling was begun, an S type Pitot tube was used to measure the flow velocity of the exhaust gas from the engine. After calculating the flow rate, a constant-flow sampling system that was equipped with a $47 \mathrm{~mm}$ dia. quartz fiber filter (Pallflex Tissuqartz 2500QAT-UP) was installed downstream of the P2SGE's exhaust to gather the particle-phase samples. PM emissions were tested at P2SGE rotation speeds of 3,800 rpm (idling), 5,000 rpm, and 7,000 rpm with three fuels. For each combination of parameters, the experiment was performed three times (each sampling time $=15 \mathrm{~min}$ ). Sampling data were collected after the engine had been run for at least $10 \mathrm{~min}$. Fig. 1 shows the schematic diagram of the experimental system.

The quartz filters were pretreated before sampling by heating them in a muffle furnace in air for $2.5 \mathrm{~h}$ at $900^{\circ} \mathrm{C}$. The filters were dried for $24 \mathrm{~h}$ in a desiccator at $25 \pm 1^{\circ} \mathrm{C}$ and a relative humidity of $40 \pm 5 \%$ before and after each sampling. They were then weighed on an electronic seven-digit balance (UMX2, Mettler Toledo) with a resolution of $0.1 \mu \mathrm{g}$.

\subsection{Water-soluble Ion Analysis}

Before water-soluble ions were analyzed, collected particles were extracted for 120 minutes from quarter sections of each quartz filter in an ultrasonic bath using $10 \mathrm{~mL}$ of $n$-hexane. Then, $10 \mathrm{~mL}$ of deionized water (specific resistance $\geq 18.3 \mathrm{M} \Omega \mathrm{m}$ ) was added and ultrasonic extraction was conducted for another 120 minutes. Next, the $\mathrm{n}$-hexane was removed by purging with ultrapure nitrogen. Finally, each extraction solution was filtered using a C18 pretreatment column and a cellulose acetate filter in that order, and then stored in a plastic vial in a refrigerator at $4^{\circ} \mathrm{C}$ before chemical analysis by ion chromatography (IC) (DIONEX ICS-3000).

Table 1. The physicochemical properties of two-stroke engine oils.

\begin{tabular}{llllll}
\hline \multirow{2}{*}{ Test Item } & \multirow{2}{*}{ Unit } & \multicolumn{3}{c}{ two-stroke engine oils } & Method \\
\cline { 3 - 5 } & & SLS & LS & MS & ASTM D445-17a \\
\hline Kinematic Viscosity @ $40^{\circ} \mathrm{C}$ & $\mathrm{cSt}$ & 52.73 & 48.46 & 62.47 & ASTM D445-17a \\
Kinematic Viscosity @ $100^{\circ} \mathrm{C}$ & $\mathrm{cSt}$ & 8.20 & 7.83 & 8.90 & ASTM D2270-10(2016) \\
Viscosity Index & - & 127 & 129 & 118 & ASTM D4052-18a \\
Specific Gravity @ $15.6^{\circ} \mathrm{C}$ & - & 0.8645 & 0.8680 & 0.8682 & ASTM D874-13a(2018) \\
Sulfate Ash & $\mathrm{wt} \%$ & 0.13 & 0.15 & 0.01 & ASTM D664A-18 \\
Total Acid Number & $\mathrm{mg}(\mathrm{KOH}) \mathrm{g}^{-1}$ & 0.43 & 0.46 & 0.22 & ASTM D2896B-15 \\
Total Base Number & $\mathrm{mg}(\mathrm{KOH}) \mathrm{g}^{-1}$ & 2.7 & 2.8 & 0.46 & ASTM D524-15 \\
Carbon Residue, Rams & $\mathrm{wt} \%$ & 0.28 & 0.27 & 0.05 & ASTM D92-18 \\
Flash Point & ${ }^{\circ} \mathrm{C}$ & 94 & 98 & 136 & ASTM D97-17b \\
Pour Point & ${ }^{\circ} \mathrm{C}$ & -27 & -15 & -24 & \\
\hline
\end{tabular}

Data from Tsai et al. (2020). 


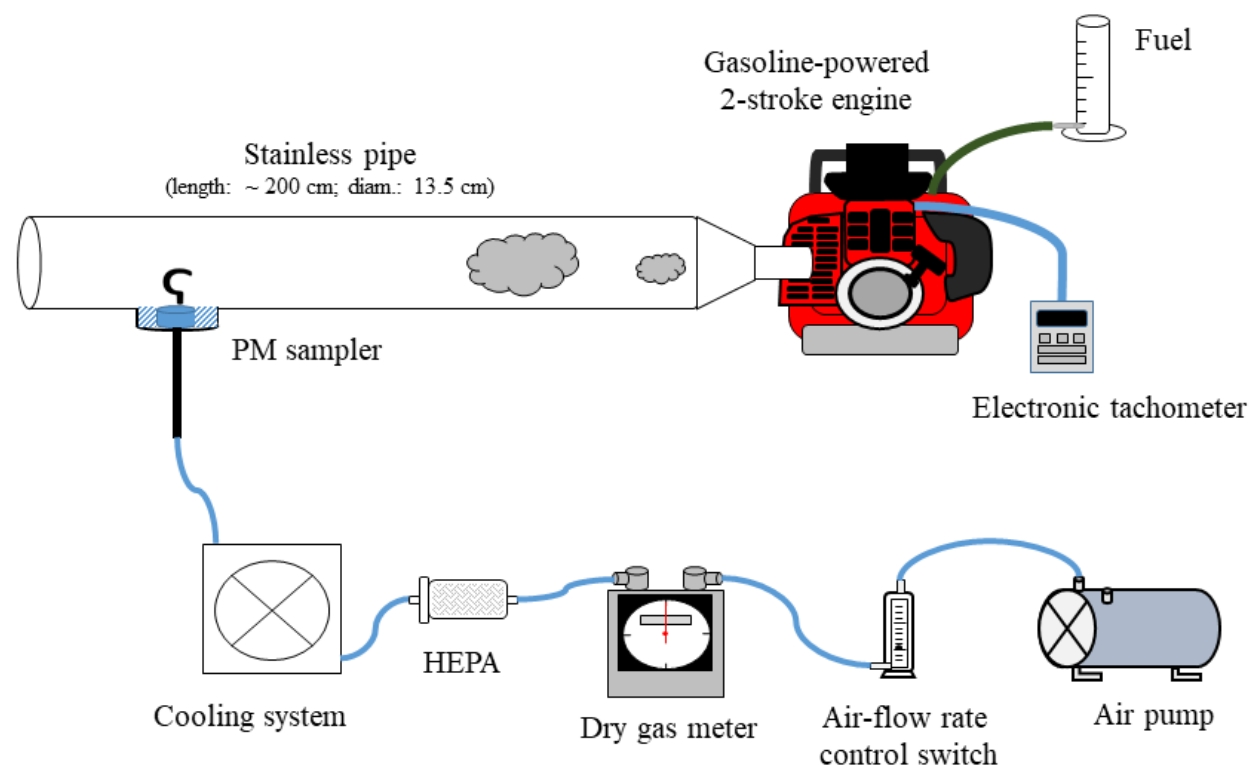

Fig. 1. Scheme of the sampling system and the P2SGE.

The method detection limits were as follows; $\mathrm{Na}^{+}, 0.038 \mathrm{ppm} ; \mathrm{K}^{+}, 0.041 \mathrm{ppm} ; \mathrm{NH}_{4}^{+}, 0.076 \mathrm{ppm}$; $\mathrm{Mg}^{2+}, 0.027 \mathrm{ppm} ; \mathrm{Ca}^{2+}, 0.077 \mathrm{ppm} ; \mathrm{Cl}^{-}, 0.046 \mathrm{ppm} ; \mathrm{NO}_{3}{ }^{-}, 0.060 \mathrm{ppm}$, and, $\mathrm{SO}_{4}{ }^{2-}, 0.021 \mathrm{ppm}$. The recovery efficiencies of these ions were $92.3-114.3 \%$ based on the IC measurements. Both field and laboratory blank samples were prepared and analyzed for each sampling and analysis. All data were corrected using filter blanks.

\subsection{Metal Analysis}

Before the particle-bound metals had been chemically analyzed, extraction was performed on one-quarter of each quartz filter for 120 minutes using an ultrasonic bath of $20 \mathrm{~mL} 10 \%(\mathrm{v} / \mathrm{v})$ $\mathrm{HNO}_{3}$ solution. Then, each sample was heated to $85^{\circ} \mathrm{C}$ for 30 minutes for digestion. The digested solution was diluted to a volume of $25 \mathrm{~mL}$ using ultra-pure water (specific resistance $\geq 18.3 \mathrm{M} \Omega \mathrm{cm}$ ) to identify 21 metals ( $\mathrm{Na}, \mathrm{Mg}$, Al, $\mathrm{K}, \mathrm{Ca}, \mathrm{Ti}, \mathrm{V}, \mathrm{Cr}, \mathrm{Mn}, \mathrm{Fe}, \mathrm{Ni}, \mathrm{Cu}, \mathrm{Zn}, \mathrm{As}, \mathrm{Sr}, \mathrm{Mo}, \mathrm{Cd}, \mathrm{Sn}, \mathrm{Sb}, \mathrm{Ba}$, and $\mathrm{Pb}$ ) by inductively coupled plasma-mass spectrometry (ICP-MS) (Agilent, 7500 series). Calibration was conducted using multi-element (metal) standards (certified reference materials (CRMs); Spex, Metuchen, USA) in a $1 \%(\mathrm{v} / \mathrm{v}) \mathrm{HNO}_{3}$ solution. Every tenth sample was spiked using the liquid standards that contained known amounts of the metal elements that were analyzed. The CRMs were also used as quality control standards.

In the analyses of elements from ICP-MS measurements, the method detection limits for $\mathrm{Na}$, $\mathrm{Mg}, \mathrm{Al}, \mathrm{K}, \mathrm{Ca}, \mathrm{Ti}, \mathrm{V}, \mathrm{Cr}, \mathrm{Mn}, \mathrm{Fe}, \mathrm{Ni}, \mathrm{Cu}, \mathrm{Zn}, \mathrm{As}, \mathrm{Sr}, \mathrm{Mo}, \mathrm{Cd}, \mathrm{Sn}, \mathrm{Sb}, \mathrm{Ba}$, and $\mathrm{Pb}$ were 6.12, 5.22, 3.16, $19.3,24.3,0.36,0.04,0.14,0.03,2.22,0.03,0.31,5.27,0.31,0.20,0.99,0.02,3.15,0.12,0.51$, and $0.06 \mathrm{ppb}$, respectively. The recovery efficiencies of 21 metals were $91.2-108.4 \%$. Both field and laboratory blank samples were prepared and analyzed for each sampling and analysis. All data were corrected using filter blanks.

\section{RESULTS AND DISCUSSION}

\subsection{PM Concentrations and Emission Factors in the Exhaust}

Fig. 2 presents the mass concentrations and emission factors (based on fuel consumption ( $\mathrm{EF}_{\mathrm{FC}}$ ) and output energy (EFOE)) of PM in the exhausts emitted from P2SGE that was operated at idling (0 kW), mid-load ( 1.5 kW), and high-load ( 1.9 kW) with 4 vol.\% of SLS, LS, or MS as the additive in 92-gasoline. Experimental results show that the mass concentration of the PM from P2SGE was the lowest when LS was used (947-1,331 $\mathrm{mg} \mathrm{Nm}^{-3}$, with an average of $\left.1,167 \mathrm{mg} \mathrm{Nm}^{-3}\right)$, followed by SLS $\left(1,020-1,913 \mathrm{mg} \mathrm{Nm}^{-3}\right.$, with an average of $\left.1,543 \mathrm{mg} \mathrm{Nm}^{-3}\right)$ and MS $\left(1,289-2,405 \mathrm{mg} \mathrm{Nm}^{-3}\right.$, with an average of $1,934 \mathrm{mg} \mathrm{Nm}^{-3}$ ) at all engine loads. Accordingly, the PM concentration 

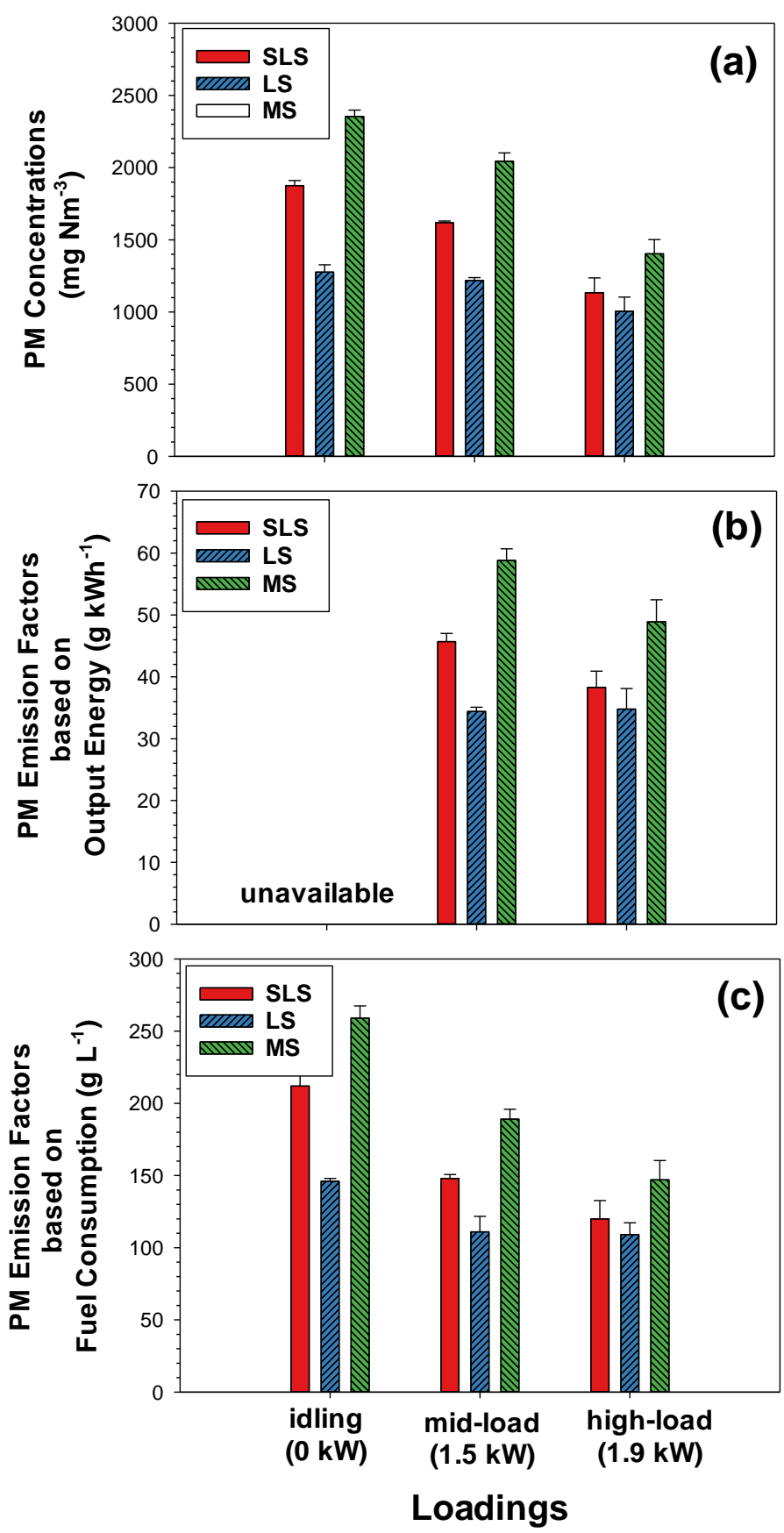

Fig. 2. Mass concentrations (a) and emission factors ((b) and (c)) of PM from a P2SGE by using SLS, LS, and MS operated at various loads.

decreased as the P2SGE load increased regardless of the lubricant used (as shown in Fig. 2(a)). Moreover, this trend was also observed for $\mathrm{EF}_{\mathrm{FC}}$ and $\mathrm{EF}_{\mathrm{OE}}$ (as shown in Figs. 2(b) and 2(c)). This phenomenon may be related to the sampling temperature was higher at the high-load $\left(85-90^{\circ} \mathrm{C}\right)$ than at idling $\left(40-45^{\circ} \mathrm{C}\right)$ and mid-load $\left(50-55^{\circ} \mathrm{C}\right)$, and thus the P2SGE had a better combustion efficiency when operated at high-load and helped to inhibit PM formation.

Adding SLS or LS reduced the PM concentration below that obtained when MS was added at a given engine load; adding LS reduced the PM concentration (38.2\%) by almost twice as much as adding SLS (20.1\%), perhaps because higher flash point of $\mathrm{MS}\left(136^{\circ} \mathrm{C}\right)$ (as shown in Table 1 ) leads to less complete combustion and higher PM emission than with the other two lubricant oils, which have lower flash points $\left(\mathrm{LS}=98^{\circ} \mathrm{C}\right.$ and $\mathrm{SLS}=94^{\circ} \mathrm{C}$ ), at the same engine load (Tsai et al., 2020). Generally, the flash point of oil is the lowest temperature of oil at which the application of 
defined test flames leads the vapors above the surface to ignition and the release of vapors at this temperature is not sufficiently rapid to sustain combustion (Ljubas et al., 2010). Once the flash point of two-stroke engine oil was getting higher, it was less likely to be burned entirely (in order to protect the engine cylinder) and remained in the exhausts during the combustion process, resulting in more significant amounts of emission (as displayed in Fig. 3). On the other hand, although the flash points of SLS and LS were similar, the PM emissions of using these two fuels differed by about $30 \%$, which was possibly associated with their different viscosities. As is well known, the higher the viscosity of the oil, the less favorable it is to be atomized, eventually leading to more PM generation during the combustion process.

\subsection{Concentrations and Emission Factors of PM-bound Water-soluble lons}

The mass concentrations of $\Sigma$ lons (sum of 8 ions, namely $\mathrm{Na}^{+}, \mathrm{NH}_{4}^{+}, \mathrm{K}^{+}, \mathrm{Mg}^{2+}, \mathrm{Ca}^{2+}, \mathrm{Cl}^{-}, \mathrm{NO}_{3}{ }^{-}$, and $\mathrm{SO}_{4}{ }^{2-}$ ) on PM from the P2SGE's exhausts by using 4 vol.\% of SLS, LS, or MS as the additive in 92-gasoline were 1,213-2,115 (average 1,627 $\mathrm{g} \mathrm{N} \mathrm{N}^{-3}$ ), 660-1,047 (average $858 \mu \mathrm{g} \mathrm{Nm}^{-3}$ ), and 1,359-1,850 $\mu \mathrm{g} \mathrm{Nm}^{-3}$ (average $1,614 \mu \mathrm{g} \mathrm{Nm}^{-3}$ ), respectively (Table 2). Additionally, based on fuel consumption, emission factors of $\Sigma$ lons were the lowest when utilizing the LS additive (average $89.7 \mathrm{mg} \mathrm{L}^{-}$fuel $^{-1}$ ), followed by the MS and SLS (165 and $168 \mathrm{mg} \mathrm{L}^{-f_{u e l}}{ }^{-1}$, in average, respectively) (Fig. 4). Similarly, based on output energy, the order of Elons magnitude was also LS (average $30.4 \mathrm{mg} \mathrm{kWh}^{-1}$ ) < MS (average $55.7 \mathrm{mg} \mathrm{kWh}^{-1}$ ) $<\mathrm{SLS}$ (average $57.7 \mathrm{mg} \mathrm{kWh}^{-1}$ ). The dominant water-soluble ions among eight considered $\left(\mathrm{Na}^{+}, \mathrm{NH}_{4}{ }^{+}, \mathrm{K}^{+}, \mathrm{Mg}^{2+}, \mathrm{Ca}^{2+}, \mathrm{Cl}^{-}, \mathrm{NO}_{3}{ }^{-}\right.$, and $\mathrm{SO}_{4}{ }^{2-}$ ) on PM that emitted from the P2SGE that was fueled with different lubricants and operated at various loads were $\mathrm{Ca}^{2+}, \mathrm{Na}^{+}$, and $\mathrm{SO}_{4}{ }^{2-}$, with $20.5 \%, 31.4 \%$, and $13.6 \%$, in average, respectively, as displayed in Fig. 5. Our results are consistent with the findings of the preceding study by Yang et al. (2019), who found that $\mathrm{Ca}^{2+}$ and $\mathrm{SO}_{4}{ }^{2-}$ dominated the $\mathrm{PM}_{2.5}$-bound ions $\left(\mathrm{K}^{+}, \mathrm{Mg}^{2+}, \mathrm{Ca}^{2+}, \mathrm{Cl}^{-}\right.$, $\mathrm{NO}_{3}{ }^{-}$, and $\mathrm{SO}_{4}{ }^{2-}$ ). Related studies have demonstrated that $\mathrm{Na}^{+}$and $\mathrm{Ca}^{2+}$ are generated by the incomplete combustion of lubricant oils (Jaiprakash and $\mathrm{Habib}, 2017$ ), while $\mathrm{NO}_{3}{ }^{-}$and $\mathrm{SO}_{4}{ }^{2-}$ were generated mainly by an atmospheric photochemical reaction of compounds in fossil fuel emissions ( $\mathrm{NO}_{\mathrm{x}}$ and $\mathrm{SO}_{\mathrm{x}}$ ) (Chiang et al., 2012; Alves et al., 2015). Moreover, Hao et al. (2019) identified that the primary water-soluble ion species on $\mathrm{PM}_{2.5}$ were $\mathrm{NO}_{3}{ }^{-}, \mathrm{Cl}^{-}, \mathrm{Na}^{+}$, and $\mathrm{Ca}^{2+}$ from light-duty diesel vehicles, $\mathrm{NO}_{3}{ }^{-}, \mathrm{Ca}^{2+}, \mathrm{SO}_{4}{ }^{2-}$, and $\mathrm{Na}^{+}$from heavy-duty diesel vehicles, and $\mathrm{NO}_{3}{ }^{-}$, $\mathrm{Ca}^{2+}, \mathrm{Na}^{+}$, and $\mathrm{Cl}^{-}$from light-duty gasoline vehicles. In another related study conducted by $\mathrm{Yu}$ et al. (2020), they reported that the primary water-soluble ions on $\mathrm{PM}_{2.5}$ in the exhausts from nonroad construction equipment (including excavators, bulldozers, wheel loaders, stackers, road rollers, graders, and rotary drills) were $\mathrm{NO}_{3}{ }^{-}, \mathrm{SO}_{4}{ }^{2-}, \mathrm{NH}_{4}{ }^{+}$, and $\mathrm{Ca}^{2+}$, regardless of operational load.

Our analysis demonstrated that the $\mathrm{A} / \mathrm{C}$ (summation of equivalent concentrations of anions to that of cations) ratio increased with the engine load but were all less than 0.5 as presented in Table 2. Nevertheless, the $A / C$ ratios that were calculated from the data in several previous gasoline exhausts studies were all less than 0.2 (Table 3), supporting our finding. This phenomenon may be related to the fact that lubricant oil usually contains a certain amount of $\mathrm{CaCO}_{3}$ which

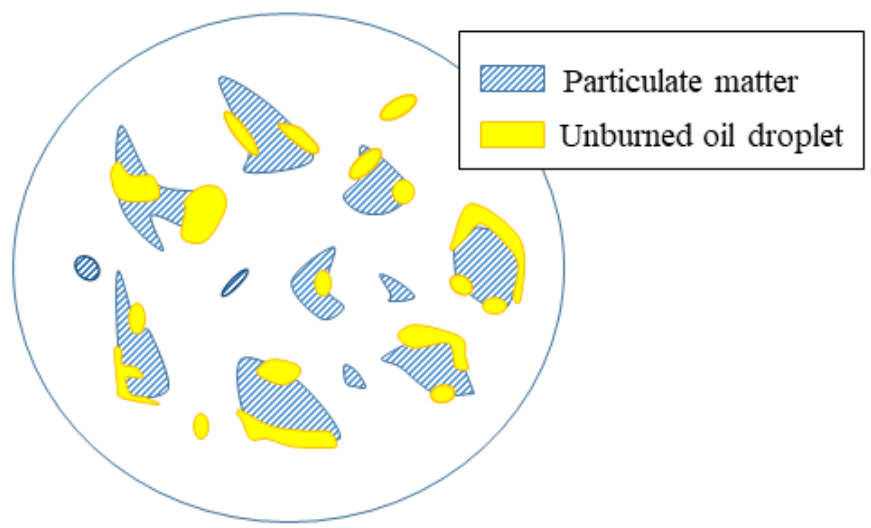

Fig. 3. Schematic diagram of particulate matter and unburned lubricating oil in gasoline engine exhaust. 
Table 2. Mass concentrations of particle-bound water-soluble ions and $A / C$ ratios.

\begin{tabular}{|c|c|c|c|c|c|c|c|c|c|}
\hline & \multicolumn{3}{|c|}{ idling $(0 \mathrm{~kW})$} & \multicolumn{3}{|c|}{ mid-load (1.5 kW) } & \multicolumn{3}{|c|}{ high-load (1.9 kW) } \\
\hline & SLS & LS & MS & SLS & LS & MS & SLS & LS & MS \\
\hline \multicolumn{10}{|c|}{ Concentrations $\left(\mu \mathrm{g} \mathrm{Nm}^{-3}\right)(\mathrm{N}=3)$} \\
\hline \multirow[t]{2}{*}{$\mathrm{Na}^{+}$} & 619 & 219 & 847 & 346 & 117 & 804 & 264 & 72.4 & 593 \\
\hline & $( \pm 79.2)$ & $( \pm 16.0)$ & $( \pm 72.8)$ & $( \pm 53.5)$ & $( \pm 7.14)$ & $( \pm 97.8)$ & $( \pm 85.3)$ & $( \pm 5.57)$ & $( \pm 77.0)$ \\
\hline \multirow[t]{2}{*}{$\mathrm{NH}_{4}^{+}$} & 29.3 & 61.1 & 50.8 & 87.2 & 81.1 & 108 & 274 & 102 & 245 \\
\hline & $( \pm 3.72)$ & $( \pm 13.6)$ & $( \pm 18.3)$ & $( \pm 37.8)$ & $( \pm 7.54)$ & $( \pm 21.7)$ & $( \pm 53.8)$ & $( \pm 0.89)$ & $( \pm 82.1)$ \\
\hline \multirow[t]{2}{*}{$\mathrm{K}^{+}$} & 48.2 & 23.9 & 46.5 & 57.9 & 24.0 & 59.1 & 64.1 & 28.0 & 78.3 \\
\hline & $( \pm 6.64)$ & $( \pm 18.3)$ & $( \pm 4.44)$ & $( \pm 18.6)$ & $( \pm 11.4)$ & $( \pm 11.0)$ & $( \pm 19.9)$ & $( \pm 3.19)$ & $( \pm 8.59)$ \\
\hline \multirow[t]{2}{*}{$\mathrm{Mg}^{2+}$} & 22.0 & 19.8 & 16.2 & 27.1 & 53.8 & 28.0 & 24.0 & 47.5 & 14.9 \\
\hline & $( \pm 9.02)$ & $( \pm 6.70$ & $( \pm 4.25)$ & $( \pm 12.4)$ & $( \pm 16.5)$ & $( \pm 7.68)$ & $( \pm 6.86)$ & $( \pm 9.04)$ & $( \pm 5.50)$ \\
\hline \multirow[t]{2}{*}{$\mathrm{Ca}^{2+}$} & 250 & 200 & 145 & 364 & 229 & 190 & 413 & 309 & 229 \\
\hline & $( \pm 47.1)$ & $( \pm 35.9)$ & $( \pm 29.0)$ & $( \pm 25.3)$ & $( \pm 22.7)$ & $( \pm 35.3)$ & $( \pm 37.8)$ & $( \pm 14.6)$ & $( \pm 13.9)$ \\
\hline \multirow[t]{2}{*}{$\mathrm{Cl}^{-}$} & 39.1 & 29.0 & 38.3 & 111 & 46.9 & 113 & 494 & 115 & 320 \\
\hline & $( \pm 3.36)$ & $( \pm 11.7)$ & $( \pm 3.87)$ & $( \pm 21.3)$ & $( \pm 15.4)$ & $( \pm 24.1)$ & $( \pm 79.0)$ & $( \pm 2.04)$ & $( \pm 38.0)$ \\
\hline \multirow[t]{2}{*}{$\mathrm{NO}_{3}^{-}$} & 72.1 & 53.0 & 95.9 & 244 & 143 & 151 & 306 & 173 & 162 \\
\hline & $( \pm 12.6)$ & $( \pm 17.7)$ & $( \pm 29.5)$ & $( \pm 45.8)$ & $( \pm 39.4)$ & $( \pm 40.4)$ & $( \pm 65.3)$ & $( \pm 21.4)$ & $( \pm 17.5)$ \\
\hline \multirow[t]{2}{*}{$\mathrm{SO}_{4}^{2-}$} & 132 & 54.1 & 119 & 316 & 173 & 182 & 275 & 200 & 208 \\
\hline & $( \pm 14.7)$ & $( \pm 37.2)$ & $( \pm 15.3)$ & $( \pm 16.6)$ & $( \pm 67.7)$ & $( \pm 7.37)$ & $( \pm 14.6)$ & $( \pm 32.8)$ & $( \pm 27.5)$ \\
\hline \multirow[t]{2}{*}{ Elons } & 1213 & 660 & 1359 & 1555 & 867 & 1633 & 2115 & 1047 & 1850 \\
\hline & $( \pm 57.8)$ & $( \pm 67.9)$ & $( \pm 115)$ & $( \pm 96.3)$ & $( \pm 144)$ & $( \pm 78.8)$ & $( \pm 209)$ & $( \pm 42.1)$ & $( \pm 83.8)$ \\
\hline \multicolumn{10}{|c|}{ Ratio ( $N=3$ ) } \\
\hline \multirow[t]{2}{*}{$\mathrm{A} / \mathrm{C}$} & 0.11 & 0.11 & 0.10 & 0.33 & 0.27 & 0.17 & 0.48 & 0.35 & 0.30 \\
\hline & $( \pm 0.01)$ & $( \pm 0.05)$ & $( \pm 0.02)$ & $( \pm 0.02)$ & $( \pm 0.08)$ & $( \pm 0.02)$ & $( \pm 0.06)$ & $( \pm 0.03)$ & $( \pm 0.01)$ \\
\hline
\end{tabular}
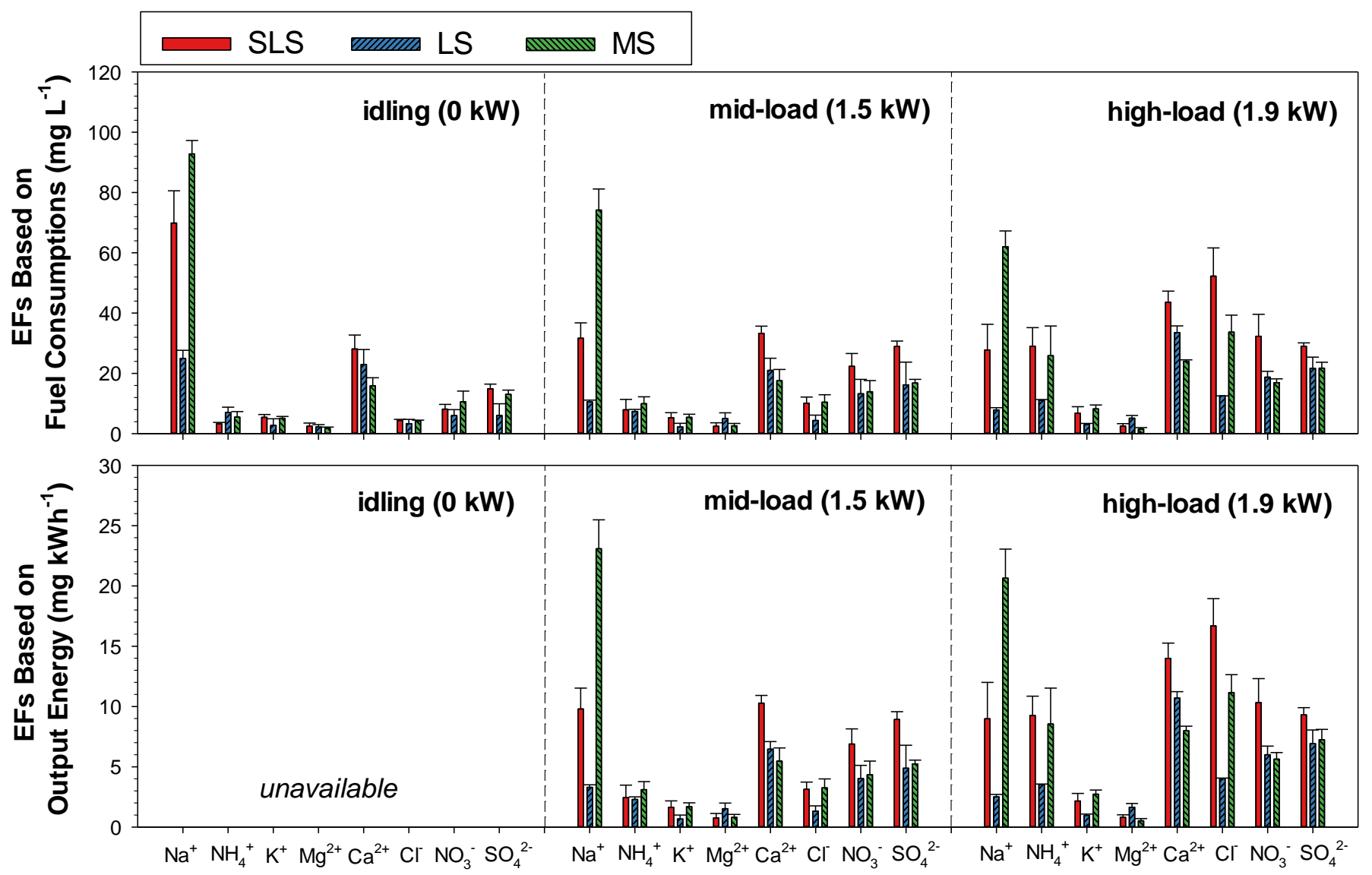

Fig. 4. Emission factors of water-soluble ions on PM from a P2SGE by using SLS, LS, and MS operated at various loads. 


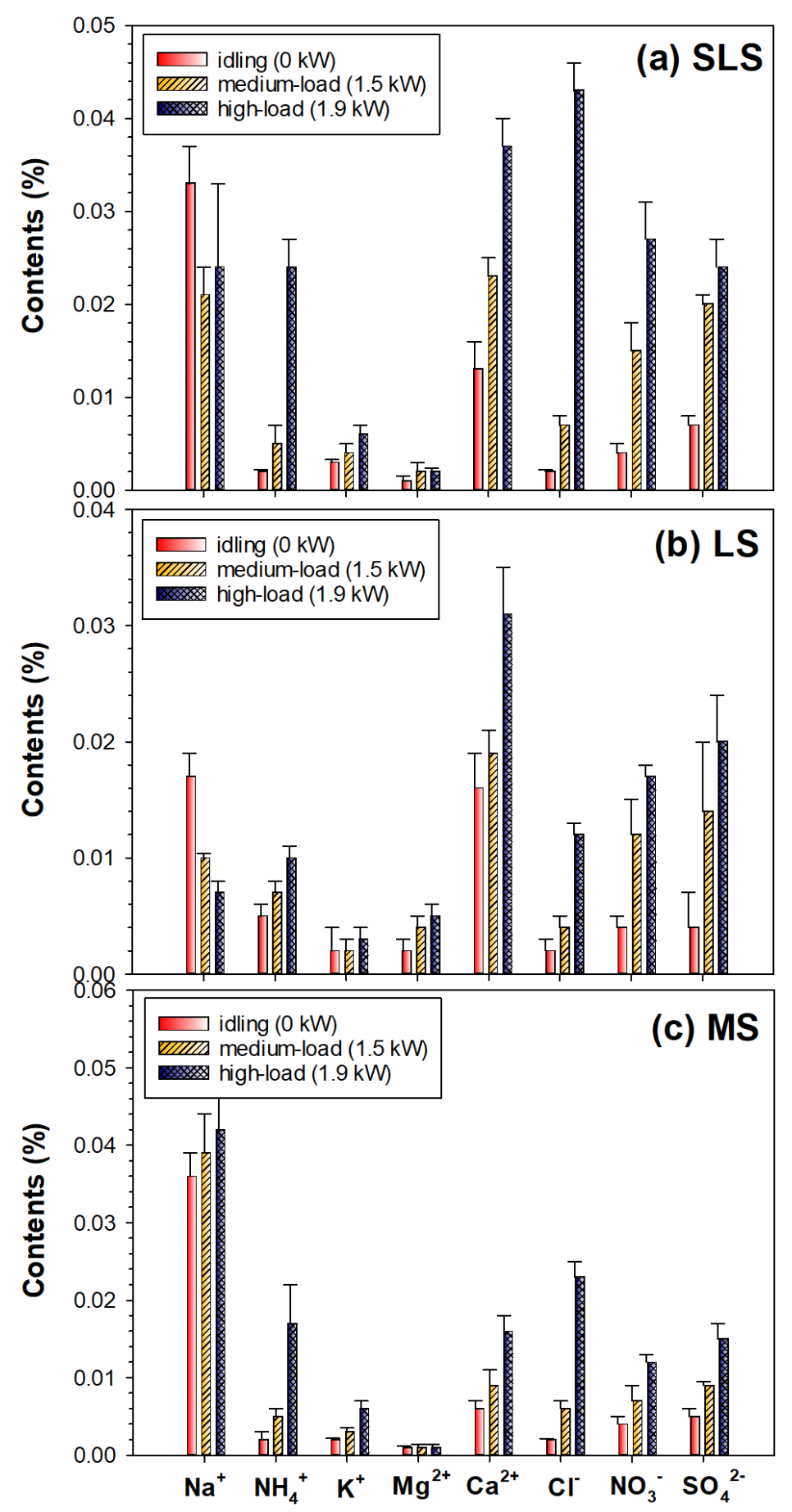

Fig. 5. Contents of water-soluble ions on PM from a P2SGE by using (a) SLS, (b) LS, and (c) MS operated at various loads.

Table 3. Summary of the relative gasoline engine researches.

\begin{tabular}{|c|c|c|c|}
\hline Types & Water-soluble ions & $\mathrm{A} / \mathrm{C}$ ratios & Reference \\
\hline 2-stroke gasoline engine (non-road) & $\begin{array}{l}\mathrm{Na}^{+}, \mathrm{NH}_{4}^{+}, \mathrm{K}^{+}, \mathrm{Mg}^{2+}, \mathrm{Ca}^{2+}, \mathrm{Cl}^{-}, \\
\mathrm{NO}_{3}{ }^{-}, \text {and } \mathrm{SO}_{4}{ }^{2-}\end{array}$ & $0.10-0.48$ & this study \\
\hline light duty gasoline engine ( 2 and 4 wheel vehicles) & $\begin{array}{l}\mathrm{Na}^{+}, \mathrm{NH}_{4}^{+}, \mathrm{Mg}^{2+}, \mathrm{Ca}^{2+}, \mathrm{Cl}^{-}, \mathrm{NO}_{3}{ }^{-}, \\
\quad \text { and } \mathrm{SO}_{4}{ }^{2-}\end{array}$ & $0.10-0.16$ & $\begin{array}{l}\text { Jaiprakash and Habib } \\
\text { (2017) }\end{array}$ \\
\hline 4-stroke gasoline engine ( 4 wheel vehicles) & $\begin{array}{l}\mathrm{K}^{+}, \mathrm{Mg}^{2+}, \mathrm{Ca}^{2+}, \mathrm{Cl}^{-}, \mathrm{NO}_{3}{ }^{-} \text {, and } \\
\mathrm{SO}_{4}{ }^{2-}\end{array}$ & 0.05 & Yang et al. (2019) \\
\hline
\end{tabular}


could maintain the lubrication of a piston during engine operation (Eastwood, 2008; Raza et al., 2018). The $\mathrm{CaCO}_{3}$ is a typical alkaline additive for preventing the deterioration of lubricant oil by oxidation and extending operational lifetime. Moreover, to prevent wear and tear on the twostroke engine, inevitably some unburned lubricant oil-droplets might be present in the exhausts (as shown in Fig. 3). At this situation, the unburned lubricant oil-droplets would be collected on the PM samples that were obtained by the filtering method. Furthermore, a mixture of deionized water and n-hexane was used herein to extract the water-soluble ions on PM, which might also cause the extraction of $\mathrm{CaCO}_{3}$ in the unburned oil-droplets. Thus, the $\mathrm{Ca}^{2+}$ content was increased and became one of the major ions on the $\mathrm{PM}$, whereas $\mathrm{CO}_{3}{ }^{2-}$ was not analyzed in this study, leading to lower $\mathrm{A} / \mathrm{C}$ ratios.

\subsection{Concentrations and Emission Factors of PM-bound Metals}

Table 4 and Fig. 6 illustrate the mass concentrations and EFs of $21 \mathrm{PM}$-bound metals ( $\mathrm{Na}, \mathrm{Mg}$, $\mathrm{Al}, \mathrm{K}, \mathrm{Ca}, \mathrm{Ti}, \mathrm{V}, \mathrm{Cr}, \mathrm{Mn}, \mathrm{Fe}, \mathrm{Ni}, \mathrm{Cu}, \mathrm{Zn}, \mathrm{As}, \mathrm{Sr}, \mathrm{Mo}, \mathrm{Cd}, \mathrm{Sn}, \mathrm{Sb}, \mathrm{Ba}$, and Pb) from the exhaust of the P2SGE with 4 vol.\% of LS, MS, and SLS lubricants in 92-gasoline. The results showed that the three metallic elements of As, Mo, and Sn were not detected in all test conditions. On average, the mass concentrations of $\Sigma$ Metals on PM from the P2SGE's exhausts by using 4 vol.\% of SLS, LS, or MS as the additive in 92-gasoline were 677-923 (average $824 \mu \mathrm{g} \mathrm{Nm}^{-3}$ ), 690-800 (average $810 \mu \mathrm{g} \mathrm{Nm}^{-3}$ ), and 576-687 $\mu \mathrm{g} \mathrm{Nm}^{-3}$ (average $603 \mu \mathrm{g} \mathrm{Nm}^{-3}$ ), respectively. In terms of emission factors, the lowest levels of $\Sigma$ Metals in the exhausts were observed by using $4 \% \mathrm{MS}$ additive (average $61.3 \mathrm{mg} \mathrm{L}^{-1}$ ), followed by LS (average $83.8 \mathrm{mg} \mathrm{L}^{-1}$ ) and SLS (average $85.2 \mathrm{mg} \mathrm{L}^{-1}$ ). According to the mass concentration or emission factor data, the amount of each metallic element from the P2SGE almost decreased with increasing loading no matter what kinds of lubricants were used.

The metallic components were divided (based on their average levels in $\Sigma$ Metals) into three groups - major metals ( $\mathrm{Na}, \mathrm{Mg}, \mathrm{Al}, \mathrm{K}, \mathrm{Ca}, \mathrm{Fe}$, and $\mathrm{Zn}, \geq \sim 1 \%$ ), sub-major metals ( $\mathrm{Cr}, \mathrm{Mn}, \mathrm{Ni}, \mathrm{Cu}$, $\mathrm{Sr}, \mathrm{Ba}$, and $\mathrm{Pb}, \sim 1$ to $0.1 \%$ ), and minor metals (Ti, V, As, Mo, Cd, Sn, and $\mathrm{Sb},<0.1 \%$ ). According to Fig. 7, the major metals represented $96.5-99.4 \%$ by mass of $\Sigma$ Metals, while the sub-major and minor metals accounted for only $0.47-3.44 \%$ and $0.04-0.14 \%$, respectively. Previous studies have identified the major PM-bound metals in gasoline engine exhaust as $\mathrm{Ca}, \mathrm{Fe}, \mathrm{Al}$, and $\mathrm{Zn}$ (Cheung et al., 2010; Hao et al., 2019); Yang et al. (2019) identified the major metal components on $\mathrm{PM}_{2.5}$ as $\mathrm{Na}, \mathrm{Ca}, \mathrm{Fe}, \mathrm{Zn}$, and Al. These observations were consistent with those herein, supporting our finding of the main metal components on PM from the P2SGE.

In addition, the most abundant metals by mass were $\mathrm{Ca}, \mathrm{Na}, \mathrm{K}$, and $\mathrm{Al}$, which accounted for $93.8 \%$ by mass of $\Sigma$ Metals when 4 -vol\% SLS was added to the fuel in the P2SGE at various loads, as reported in Table 4. The dominant four metals were $\mathrm{Ca}, \mathrm{Mg}, \mathrm{Na}$, and $\mathrm{K}(79.9 \%$ by mass of $\Sigma$ Metals) and $\mathrm{Ca}, \mathrm{Na}, \mathrm{K}$, and $\mathrm{Al}(85.3 \%$ by mass of $\Sigma$ Metals) when LS and MS were used, respectively. Consequently, the dominant metals among the 21 analyzed metals in $\mathrm{PM}$ were $\mathrm{Ca}$, $\mathrm{Na}, \mathrm{K}, \mathrm{Al}, \mathrm{Fe}, \mathrm{Mg}$, and $\mathrm{Zn}$. Those dominant metals together accounted for $98.7 \%$ by mass of $\Sigma$ Metals. At first glance, Fe and $\mathrm{Zn}$ (only about $4 \%$ each) had relatively low contents among seven primary metals. However, previous researches have confirmed that extended exposure to Fe may cause the generation of free radicals in cells and result in respiratory diseases (Kadiiska et al., 1997), whereas prolonged exposure to $\mathrm{Zn}$ leads to acute heart diseases (Chen and Lippmann, 2009). Therefore, it is necessary to regulate the limits of the hazardous metal contents in P2SGE exhausts to reduce the risk of inhaling such harmful ingredients for P2SGE operators (such as farmers).

\section{CONCLUSIONS}

Portable two-stroke gasoline engines (P2SGEs), commonly fueled by lubricant oil-gasoline mixtures, may emit more pollutants than regular gasoline engines in on-road vehicles because they are not equipped with exhaust gas control devices and typically lack maintenance. This study explored the concentrations of chemical components and metallic elements in PM emissions from the exhaust of a P2SGE. The results showed that the PM mass concentrations in the exhausts were in the order MS (average 1,934 $\mathrm{mg} \mathrm{Nm}^{-3}$ ) $>$ SLS (average 1,543 $\mathrm{mg} \mathrm{Nm}^{-3}$ ) $>$ LS (average $1,167 \mathrm{mg} \mathrm{Nm}^{-3}$ ) in all test conditions. The mass concentrations and EFs of PM using \#92-gasoline 
Table 4. Mass concentrations of particle-bound metals from a P2SGE by using SLS, LS, and MS operated at various loads.

\begin{tabular}{|c|c|c|c|c|c|c|c|c|c|}
\hline & \multicolumn{9}{|c|}{ Concentrations $\left(\mu \mathrm{g} \mathrm{Nm}^{-3}\right)(\mathrm{N}=3)$} \\
\hline & \multicolumn{3}{|c|}{ idling (0 kW) } & \multicolumn{3}{|c|}{ mid-load (1.5 kW) } & \multicolumn{3}{|c|}{ high-load (1.9 kW) } \\
\hline & SLS & LS & MS & SLS & LS & MS & SLS & LS & MS \\
\hline \multirow[t]{2}{*}{$\mathrm{Na}$} & 182 & 141 & 150 & 168 & 179 & 237 & 126 & 112 & 172 \\
\hline & $( \pm 45.8)$ & $( \pm 49.5)$ & $( \pm 84.5)$ & $( \pm 16.2)$ & $( \pm 68.8)$ & $( \pm 102)$ & $( \pm 71.2)$ & $( \pm 126)$ & $( \pm 56.8)$ \\
\hline \multirow[t]{2}{*}{$\mathrm{Mg}$} & 27.8 & 125 & 21.3 & 16.7 & 179 & 35.1 & 11.3 & 159 & 44.8 \\
\hline & $( \pm 5.75)$ & $( \pm 7.63)$ & $( \pm 10.5)$ & $( \pm 3.55)$ & $( \pm 17.7)$ & $( \pm 11.1)$ & $( \pm 1.37)$ & $( \pm 8.02)$ & $( \pm 29.3)$ \\
\hline \multirow[t]{2}{*}{ Al } & 66.8 & 96.9 & 72.7 & 31.2 & 42.5 & 54.4 & 40.3 & 58.7 & 41.6 \\
\hline & $( \pm 36.2)$ & $( \pm 86.7)$ & $( \pm 45.6)$ & $( \pm 8.92)$ & $( \pm 11.5)$ & $( \pm 16.7)$ & $( \pm 20.3)$ & $( \pm 51.1)$ & $( \pm 23.5)$ \\
\hline \multirow[t]{2}{*}{ K } & 148 & 109 & 102 & 159 & 176 & 127 & 109 & 65.1 & 89.3 \\
\hline & $( \pm 34.1)$ & $( \pm 27.4)$ & $( \pm 40.0)$ & $( \pm 11.4)$ & $( \pm 38.4)$ & $( \pm 47.2)$ & $( \pm 43.7)$ & $( \pm 73.0)$ & $( \pm 23.2)$ \\
\hline \multirow[t]{2}{*}{$\mathrm{Ca}$} & 448 & 230 & 145 & 467 & 260 & 177 & 369 & 209 & 177 \\
\hline & $( \pm 66.0)$ & $( \pm 11.4)$ & $( \pm 6.90)$ & $( \pm 25.8)$ & $( \pm 7.65)$ & $( \pm 21.3)$ & $( \pm 45.3)$ & $( \pm 13.6)$ & $( \pm 90.4)$ \\
\hline \multirow[t]{2}{*}{$\mathrm{Ti}$} & 0.78 & 0.84 & 0.30 & 0.75 & 0.22 & 0.59 & 0.73 & 0.42 & 0.22 \\
\hline & $( \pm 0.12)$ & $( \pm 0.82)$ & $( \pm 0.33)$ & $( \pm 0.11)$ & $( \pm 0.13)$ & $( \pm 0.40)$ & $( \pm 0.11)$ & $( \pm 0.46)$ & $( \pm 0.21)$ \\
\hline \multirow[t]{2}{*}{ V } & 0.09 & 0.09 & 0.06 & 0.03 & 0.08 & 0.06 & 0.02 & 0.04 & 0.05 \\
\hline & $( \pm 0.06)$ & $( \pm 0.06)$ & $( \pm 0.03)$ & $( \pm 0.02)$ & $( \pm 0.04)$ & $( \pm 0.03)$ & $( \pm 0.02)$ & $( \pm 0.01)$ & $( \pm 0.03)$ \\
\hline \multirow[t]{2}{*}{$\mathrm{Cr}$} & 1.08 & 0.88 & 0.70 & 0.65 & 0.86 & 1.81 & 0.35 & 0.35 & 2.11 \\
\hline & $( \pm 0.23)$ & $( \pm 0.37)$ & $( \pm 0.64)$ & $( \pm 0.45)$ & $( \pm 0.12)$ & $( \pm 0.70)$ & $( \pm 0.33)$ & $( \pm 0.03)$ & $( \pm 1.86)$ \\
\hline \multirow[t]{2}{*}{$\mathrm{Mn}$} & 0.20 & 0.64 & 0.13 & 0.29 & 0.34 & 0.82 & 0.31 & 0.10 & 3.56 \\
\hline & $( \pm 0.11)$ & $( \pm 0.24)$ & $( \pm 0.12)$ & $( \pm 0.12)$ & $( \pm 0.25)$ & $( \pm 0.63)$ & $( \pm 0.35)$ & $( \pm 0.07)$ & $( \pm 5.39)$ \\
\hline \multirow[t]{2}{*}{$\mathrm{Fe}$} & 33.0 & 31.2 & 39.0 & 13.1 & 17.6 & 35.7 & 11.4 & 13.8 & 19.0 \\
\hline & $( \pm 4.28)$ & $( \pm 5.14)$ & $( \pm 19.5)$ & $( \pm 2.03)$ & $( \pm 5.65)$ & $( \pm 23.3)$ & $( \pm 6.59)$ & $( \pm 2.94)$ & $( \pm 7.45)$ \\
\hline \multirow[t]{2}{*}{$\mathrm{Ni}$} & 1.73 & 1.50 & 1.83 & 0.62 & 0.37 & 0.33 & 0.51 & 0.30 & 12.1 \\
\hline & $( \pm 0.47)$ & $( \pm 0.50)$ & $( \pm 1.65)$ & $( \pm 0.09)$ & $( \pm 0.12)$ & $( \pm 0.15)$ & $( \pm 0.11)$ & $( \pm 0.16)$ & $( \pm 20.5)$ \\
\hline \multirow[t]{2}{*}{$\mathrm{Cu}$} & 1.85 & 1.79 & 1.69 & 1.14 & 1.26 & 1.90 & 0.76 & 0.83 & 1.66 \\
\hline & $( \pm 0.04)$ & $( \pm 0.47)$ & $( \pm 0.37)$ & $( \pm 0.36)$ & $( \pm 0.35)$ & $( \pm 0.60)$ & $( \pm 0.36)$ & $( \pm 0.13)$ & $( \pm 0.99)$ \\
\hline \multirow[t]{2}{*}{$\mathrm{Zn}$} & 8.45 & 56.7 & 6.95 & 12.1 & 80.1 & 9.65 & 5.27 & 68.4 & 10.1 \\
\hline & $( \pm 2.91)$ & $( \pm 14.6)$ & $( \pm 1.55)$ & $( \pm 1.22)$ & $( \pm 5.21)$ & $( \pm 1.71)$ & $( \pm 2.39)$ & $( \pm 2.11)$ & $( \pm 1.71)$ \\
\hline As & N.D. & N.D. & N.D. & N.D. & N.D. & N.D. & N.D. & N.D. & N.D. \\
\hline \multirow[t]{2}{*}{$\mathrm{Sr}$} & 1.04 & 1.11 & 0.58 & 0.74 & 0.77 & 0.84 & 0.51 & 0.42 & 0.73 \\
\hline & $( \pm 0.21)$ & $( \pm 0.55)$ & $( \pm 0.04)$ & $( \pm 0.15)$ & $( \pm 0.09)$ & $( \pm 0.20$ & $( \pm 0.05)$ & $( \pm 0.05)$ & $( \pm 0.52)$ \\
\hline Mo & N.D. & N.D. & N.D. & N.D. & N.D. & N.D. & N.D. & N.D. & N.D. \\
\hline \multirow[t]{2}{*}{$\mathrm{Cd}$} & 0.07 & 0.03 & 0.03 & 0.06 & 0.03 & 0.11 & 0.02 & 0.03 & 0.04 \\
\hline & $( \pm 0.06)$ & $( \pm 0.01)$ & $( \pm 0.01)$ & $( \pm 0.02)$ & $( \pm 0.01)$ & $( \pm 0.04$ & $( \pm 0.01)$ & $( \pm 0.01)$ & $( \pm 0.01)$ \\
\hline Sn & N.D. & N.D. & N.D. & N.D. & N.D. & N.D. & N.D. & N.D. & N.D. \\
\hline \multirow[t]{2}{*}{$\mathrm{Sb}$} & 0.26 & 0.12 & 0.09 & 0.11 & 0.06 & 0.11 & 0.06 & 0.06 & 0.07 \\
\hline & $( \pm 0.10)$ & $( \pm 0.04)$ & $( \pm 0.05)$ & $( \pm 0.03)$ & $( \pm 0.01)$ & $( \pm 0.06)$ & $( \pm 0.02)$ & $( \pm 0.002)$ & $( \pm 0.04)$ \\
\hline \multirow[t]{2}{*}{$\mathrm{Ba}$} & 1.07 & 1.98 & 1.05 & 0.64 & 1.49 & 1.55 & 1.07 & 1.44 & 0.58 \\
\hline & $( \pm 0.66)$ & $( \pm 0.56)$ & $( \pm 1.39)$ & $( \pm 0.68)$ & $( \pm 0.79)$ & $( \pm 0.86)$ & $( \pm 0.69)$ & $( \pm 0.65)$ & $( \pm 0.21)$ \\
\hline \multirow[t]{2}{*}{$\mathrm{Pb}$} & 0.27 & 0.94 & 0.48 & 0.06 & 0.54 & 2.95 & 0.15 & 0.31 & 0.69 \\
\hline & $( \pm 0.26)$ & $( \pm 1.00)$ & $( \pm 0.46)$ & $( \pm 0.04)$ & $( \pm 0.22)$ & $( \pm 1.68)$ & $( \pm 0.21)$ & $( \pm 0.27)$ & $( \pm 0.58)$ \\
\hline ¿Metals & 923 & 800 & 544 & 873 & 941 & 687 & 677 & 690 & 576 \\
\hline & $( \pm 99.6)$ & $( \pm 130)$ & $( \pm 158)$ & $( \pm 60.9)$ & $( \pm 83.1)$ & $( \pm 136)$ & $( \pm 90.6)$ & $( \pm 243)$ & $( \pm 163)$ \\
\hline
\end{tabular}

N.D.: Not Detected.

with $4 \%$ engine oil (either SLS or LS or MS has been added) decreased as the engine load increased. Adding SLS or LS to gasoline reduced the PM emission levels by $38.2 \%$ or $20.1 \%$, respectively, below that achieved by adding MS. Based on fuel consumption, emission factors of Ilons were the lowest when utilizing the LS additive (average $89.7 \mathrm{mg} \mathrm{L-fuel}^{-1}$ ), followed by the MS and SLS (165 and $168 \mathrm{mg} \mathrm{L-fuel}^{-1}$, in average, respectively). The dominant water-soluble ion species on the PM were $\mathrm{Ca}^{2+}(20.5 \%), \mathrm{Na}^{+}(31.4 \%)$, and $\mathrm{SO}_{4}{ }^{2-}(13.6 \%)$. The ratios of the sum of 


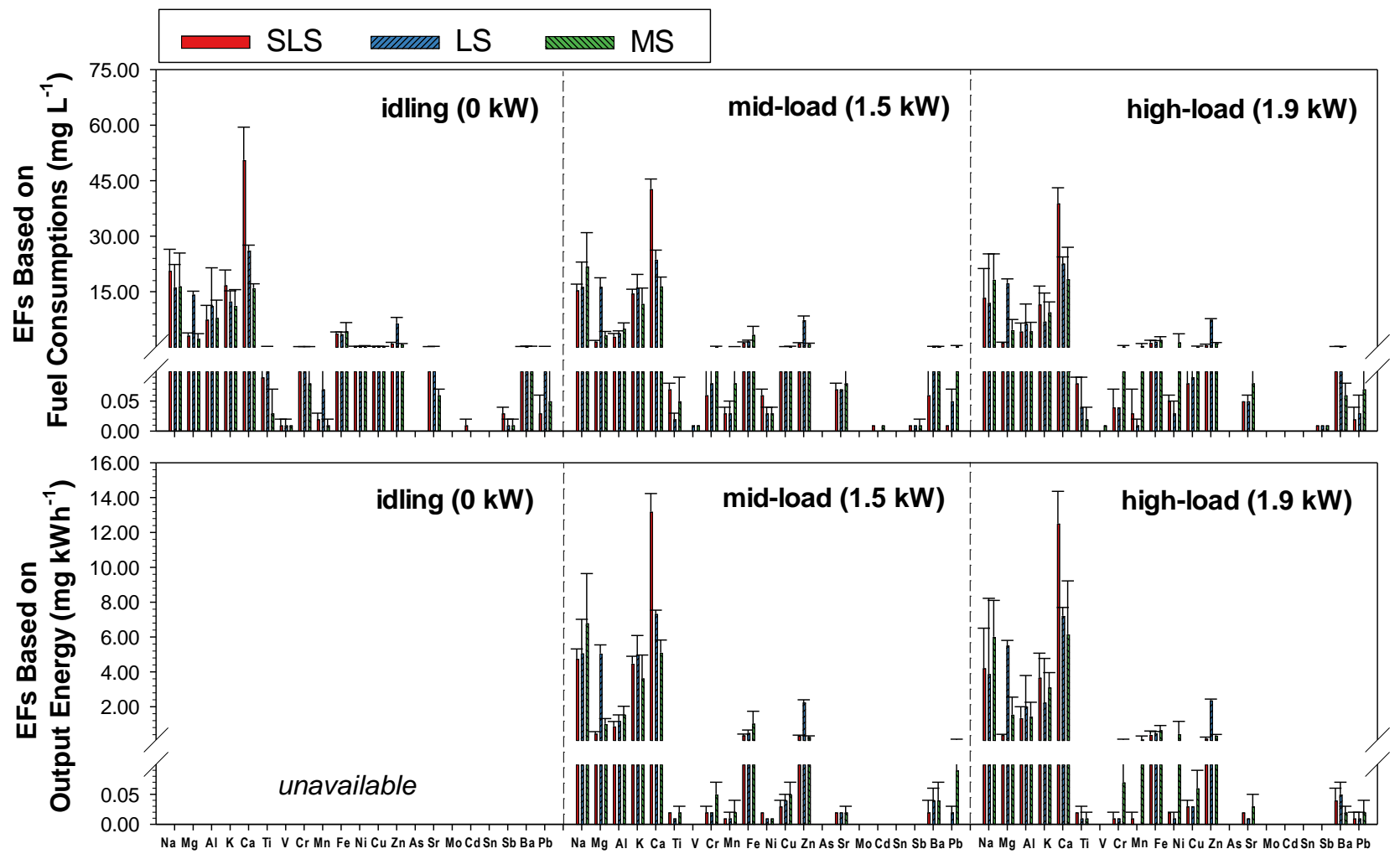

Fig. 6. Emission factors of metals on PM from a P2SGE by using SLS, LS, and MS operated at various loads.

\section{(a). Major Metal}

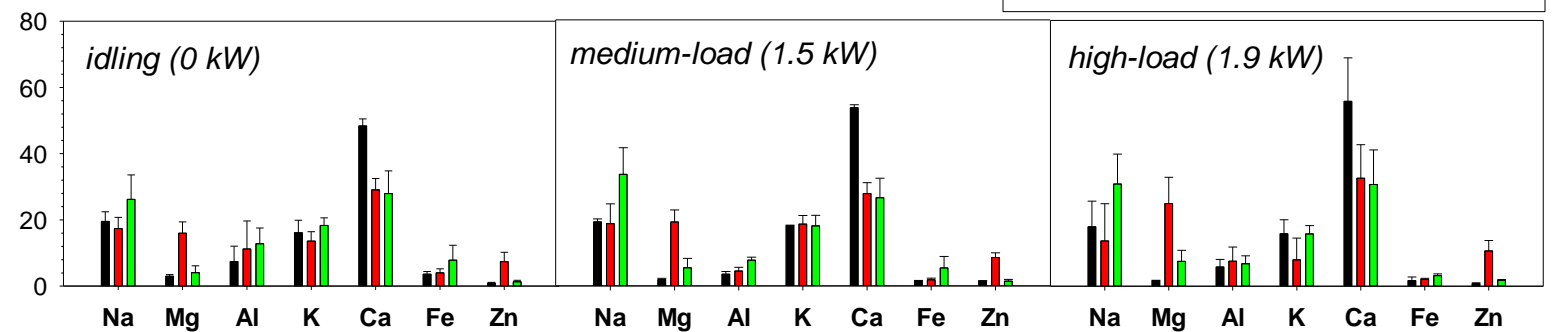

\section{(b). Submajor Metal}

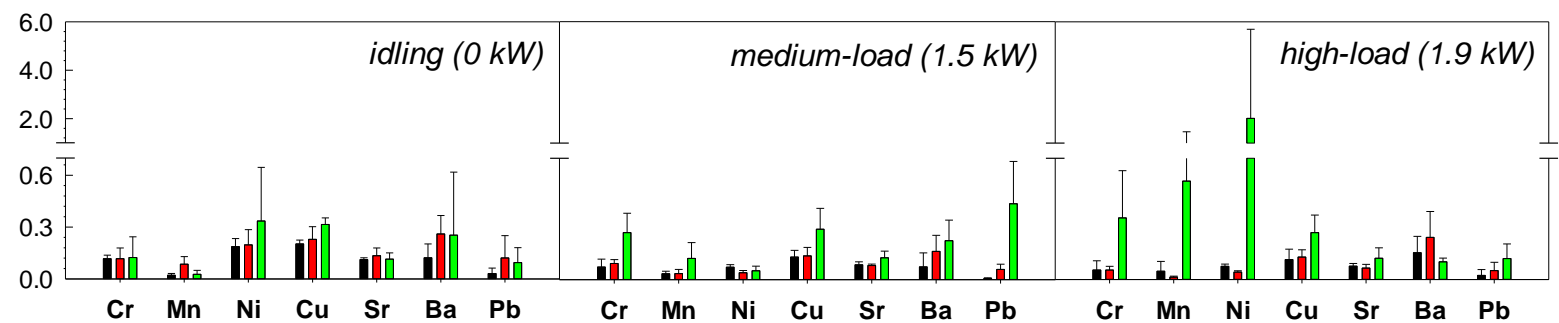

\section{(c). Minor Metal}

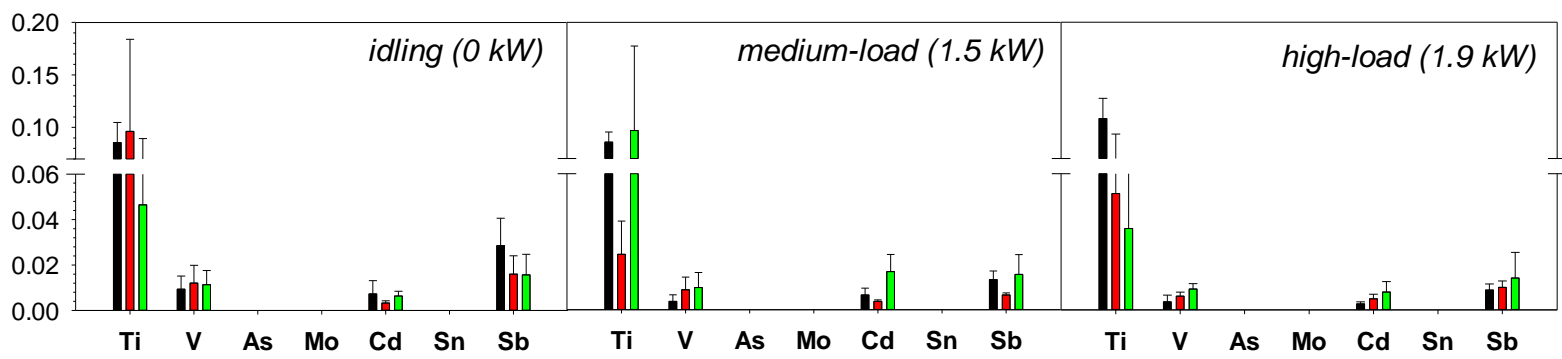

Fig. 7. Fractions of (a) major, (b) submajor, and (c) minor metals from a P2SGE by using SLS, LS, and MS operated at various loads. 
equivalent concentrations of anions to that of cations $(A / C)$ increased with the increase of engine load, although all the $A / C$ ratios were lower than 0.5 . In terms of emission factors, the lowest levels of $\Sigma$ Metals in the exhausts were observed by using MS additive (average $61.3 \mathrm{mg} \mathrm{L}^{-1}$ ), followed by LS (average $83.8 \mathrm{mg} \mathrm{L}^{-1}$ ) and SLS (average $85.2 \mathrm{mg} \mathrm{L}^{-1}$ ). Despite the difference in blended fuels, the dominant metallic elements on $\mathrm{PM}$ were $\mathrm{Ca}, \mathrm{Na}, \mathrm{K}, \mathrm{Al}, \mathrm{Fe}, \mathrm{Mg}$, and $\mathrm{Zn}$ (over $90 \%$ from $\Sigma$ Metals) at all tested conditions. The subdominant metals ( $\mathrm{Cr}, \mathrm{Mn}, \mathrm{Ni}, \mathrm{Cu}, \mathrm{Sr}, \mathrm{Ba}$, and $\mathrm{Pb}$ ) accounted for $0.5-3.5 \%$ of the PM by mass, while the trace metals (Ti, V, As, Mo, Cd, Sn, and $\mathrm{Sb}$ ) accounted for only $0.1 \%$ PM mass.

\section{ACKNOWLEDGMENTS}

The authors would like to thank the Ministry of Science and Technology of the Republic of China, Taiwan, for financially supporting this research under contract MOST 107-2221-E-020-001.

\section{REFERENCES}

Alves, C.A., Barbosa, C., Rocha, S., Calvo, A., Nunes, T., Cerqueira, M., Pio, C., Karanasiou, A., Querol, X. (2015). Elements and polycyclic aromatic hydrocarbons in exhaust particles emitted by light-duty vehicles. Environ. Sci. Pollut. Res. 22, 11526-11542. https://doi.org/10.1007/s11 356-015-4394-x

Beddows, D.C.S., Harrison, R.M. (2008). Comparison of average particle number emission factors for heavy and light duty vehicles derived from rolling chassis dynamometer and field studies. Atmos. Environ. 42, 7954-7966. https://doi.org/10.1016/j.atmosenv.2008.06.021

Bräuner, E.V., Forchhammer, L., Møller, P., Simonsen, J., Glasius, M., Wåhlin, P., Raaschou-Nielsen, O., Loft, S. (2007). Exposure to ultrafine particles from ambient air and oxidative stress-induced DNA damage. Environ. Health Perspect. 115, 1177-1182. https://doi.org/10.1289/ehp.9984

Calvo, A.I., Alves, C., Castro, A., Pont, V., Vicente, A.M., Fraile, R. (2013). Research on aerosol sources and chemical composition: Past, current and emerging issues. Atmos. Res. 120-121, 1-28. https://doi.org/10.1016/j.atmosres.2012.09.021

Chen, L.C., Lippmann, M. (2009). Effects of metals within ambient air particulate matter (PM) on human health. Inhalation Toxicol. 21, 1-31. https://doi.org/10.1080/08958370802105405

Chen, S.J., Cheng, S.Y., Shue, M.F., Huang, K.L., Tsai, P.J., Lin, C.C. (2006). The cytotoxicities induced by $\mathrm{PM}_{10}$ and particle-bound water-soluble species. Sci. Total Environ. 354, 20-27. https://doi.org/10.1016/j.scitotenv.2004.11.012

Cheung, K.L., Ntziachristos, L., Tzamkiozis, T., Schauer, J.J., Samaras, Z., Moore, K.F., Sioutas, C. (2010). Emissions of particulate trace elements, metals and organic species from gasoline, diesel, and biodiesel passenger vehicles and their relation to oxidative potential. Aerosol Sci. Technol. 44, 500-513. https://doi.org/10.1080/02786821003758294

Chiang, H.L., Lai, Y.M., Chang, S.Y. (2012). Pollutant constituents of exhaust emitted from lightduty diesel vehicles. Atmos. Environ. 47, 399-406. https://doi.org/10.1016/j.atmosenv.2011.1 0.045

Eastwood, P. (2008). Particulate emissions from vehicles. John Wiley \& Sons.

Hao, Y., Gao, C., Deng, S., Yuan, M., Song, W., Lu, Z., Qiu, Z. (2019). Chemical characterization of $\mathrm{PM}_{2.5}$ emitted from motor vehicles powered by diesel, gasoline, natural gas and methanol fuel. Sci. Total Environ. 674, 128-139. https://doi.org/10.1016/j.scitotenv.2019.03.410

Hu, S., Herner, J.D., Shafer, M., Robertson, W., Schauer, J.J., Dwyer, H., Collins, J., Huai, T., Ayala, A. (2009). Metals emitted from heavy-duty diesel vehicles equipped with advanced PM and $\mathrm{NO}_{x}$ emission controls. Atmos. Environ. 43, 2950-2959. https://doi.org/10.1016/j.atmosenv.20 09.02 .052

Jaiprakash, Habib, G. (2017). Chemical and optical properties of $\mathrm{PM}_{2.5}$ from on-road operation of light duty vehicles in Delhi city. Sci. Total Environ. 586, 900-916. https://doi.org/10.1016/j.scit otenv.2017.02.070

Järup, L., Akesson, A. (2009). Current status of cadmium as an environmental health problem. Toxicol. Appl. Pharmacol. 238, 201-208. https://doi.org/10.1016/j.taap.2009.04.020

Kadiiska, M.B., Mason, R.P., Dreher, K.L., Costa, D.L., Ghio, A.J. (1997). In vivo evidence of free 
radical formation in the rat lung after exposure to an emission source air pollution particle. Chem. Res. Toxicol. 10, 1104-1108. https://doi.org/10.1021/tx970049r

Kawata, K., Yokoo, H., Shimazaki, R., Okabe, S. (2007). Classification of heavy-metal toxicity by human DNA microarray analysis. Environ. Sci. Technol. 41, 3769-3774. https://doi.org/10.102 $1 /$ es062717d

Liati, A., Pandurangi, S.S., Boulouchos, K., Schreiber, D., Dasilva, Y.A.R. (2015). Metal nanoparticles in diesel exhaust derived by in-cylinder melting of detached engine fragments. Atmos. Environ. 101, 34-40. https://doi.org/10.1016/j.atmosenv.2014.11.014

Lim, M.C.H., Ayoko, G.A., Morawska, L., Ristovski, Z.D., Jayaratne, E.R. (2007). The effects of fuel characteristics and engine operating conditions on the elemental composition of emissions from heavy duty diesel buses. Fuel 86, 1831-1839. https://doi.org/10.1016/j.fuel.2006.11.025

Lin, C.C., Chen, S.J., Huang, K.L., Hwang, W.I., Chang-Chien, G.P., Lin, W.Y. (2005). Characteristics of metals in nano/ultrafine/fine/coarse particles collected beside a heavily trafficked road. Environ. Sci. Technol. 39, 8113-8122. https://doi.org/10.1021/es048182a

Lin, C.C., Chen, S.J., Huang, K.L., Lee, W.J., Lin, W.Y., Tsai, J.H., Chaung, H.C. (2008). PAHs, PAH-induced carcinogenic potency, and particle-extract-induced cytotoxicity of traffic-related nano/ultrafine particles. Environ. Sci. Technol. 42, 4229-4235. https://doi.org/10.1021/es703107w

Lin, Y.C., Li, Y.C., Amesho, K.T.T., Shangdiar, S., Chou, F.C., Cheng, P.C. (2020). Chemical characterization of $\mathrm{PM}_{2.5}$ emissions and atmospheric metallic element concentrations in $\mathrm{PM}_{2.5}$ emitted from mobile source gasoline-fueled vehicles. Sci. Total Environ. 739, 139942. https://doi.org/10.1016/j.scitotenv.2020.139942

Lippmann, M., Ito, K., Hwang, J.S., Maciejczyk, P., Chen, L.C. (2006). Cardiovascular effects of nickel in ambient air. Environ. Health Perspect. 114, 1662-1669. https://doi.org/10.1289/ehp.9150

Ljubas, D., Krpan, H., Matanović, I. (2010). Influence of engine oils dilution by fuels on their viscosity, flash point and fire point. Nafta 61, 73-79. https://hrcak.srce.hr/49121

Maricq, M.M. (2007). Chemical characterization of particulate emissions from diesel engines: A review. J. Aerosol Sci. 38, 1079-1118. https://doi.org/10.1016/j.jaerosci.2007.08.001

Møller, P., Folkmann, J.K., Bräuner, E., Forchhammer, L., Danielsen, P.H., Risom, L., Loft, S. (2008). Air pollution, oxidative damage to DNA, and carcinogenesis. Cancer Lett. 266, 84-97. https://doi.org/10.1016/j.canlet.2008.02.030

Ramana, M.V., Ramanathan, V., Feng, Y., Yoon, S.C., Kim, S.W., Carmichael, G.R., Schauer, J.J. (2010). Warming influenced by the ratio of black carbon to sulphate and the black-carbon source. Nat. Geosci. 3, 542-545. https://doi.org/10.1038/NGEO918

Ramanathan, V., Carmichael, G. (2008). Global and regional climate changes due to black carbon. Nat. Geosci. 1, 221-227. https://doi.org/10.1038/ngeo156

Raza, M., Chen, L., Leach, F., Ding, S. (2018). A review of particulate number (PN) emissions from gasoline direct injection (GDI) engines and their control techniques. Energies 11, 1417. https://doi.org/10.3390/en11061417

Sappok, A., Kamp, C., Wong, V. (2012). Sensitivity analysis of ash packing and distribution in diesel particulate filters to transient changes in exhaust conditions. SAE Int. J. Fuels Lubr. 5, 733-750. https://doi.org/10.4271/2012-01-1093

Schneider, J., Hock, N., Weimer, S., Borrmann, S., Kirchner, U., Vogt, R., Scheer, V. (2005). Nucleation particles in diesel exhaust: Composition inferred from in situ mass spectrometric analysis. Environ. Sci. Technol. 39, 6153-6161. https://doi.org/10.1021/es049427m

Sodeman, D.A., Toner, S.M., Prather, K.A. (2005). Determination of single particle mass spectral signatures from light-duty vehicle emissions. Environ. Sci Technol. 39, 4569-4580. https://doi.org/10.1021/es0489947

Tsai, J.H., Chen, Y.R., Chen, S.J., Lin, S.L., Huang, K.L., Lin, C.C., Chiu, J.Y. (2020). Characteristics of emissions from a portable two-stroke gasoline engine. Aerosol Air Qual. Res. 20, 630-642. https://doi.org/10.4209/aaqr.2019.12.0650

Tsai, J.H., Yao, Y.C., Huang, P.H., Chiang, H.L. (2018). Fuel economy and volatile organic compound exhaust emission for motorcycles with various running mileages. Aerosol Air Qual. Res. 18, 3056-3067. https://doi.org/10.4209/aaqr.2018.07.0264

Wang, Y., Liu, H., Lee, C.F.F. (2016). Particulate matter emission characteristics of diesel engines with biodiesel or biodiesel blending: A review. Renewable Sustainable Energy Rev. 64, 569-581. https://doi.org/10.1016/j.rser.2016.06.062 
Yang, H.H., Dhital, N.B., Wang, L.C., Hsieh, Y.S., Lee, K.T., Hsu, Y.T., Huang, S.C. (2019). Chemical characterization of fine particulate matter in gasoline and diesel vehicle exhaust. Aerosol Air Qual. Res. 19, 1439-1449. https://doi.org/10.4209/aaqr.2019.04.0191

Yu, F., Li, C., Liu, J., Liao, S., Zhu, M., Xie, Y., Sha, Q., Huang, Z., Zheng, J. (2020). Characterization of particulate smoke and the potential chemical fingerprint of non-road construction equipment exhaust emission in China. Sci. Total Environ. 723, 137967. https://doi.org/10.1016/ j.scitotenv.2020.137967 